\title{
The Egyptian Phonetic Change between "n" and "i"
}

\author{
By Stefan Bojowald*
}

This study deals with the Egyptian phonetic change between " $n$ " and " $i$ ". The phenomenon has been known for half a century. Its first detailed investigation appeared in the grammar of Egyptian medical texts by Westendorf from the year 1962. In there, the phenomenon could be demonstrated in seven cases. The present contribution continues work on this topic, significantly increasing the number of examples. The material consists of writings of individual words on the one side and plays on words on the other. The period of the examples went from the Old Kingdom to the Graeco-Roman Period. In the course of the investigation, twenty two new examples could be collected. The phonetic change takes place from " $n$ " to " $i$ " and " $i$ " to " $n$ ".

Keywords: Egyptian philology, Egyptian phonology, phonetic change between " $n$ " and " $i "$

\section{Introduction}

In this article, some thoughts on the Egyptian phonetic change between "n"and "i" are articulated (for "n" see Vycichl 1990, p. 5; for "i" see Vycichl 1990, p. 5). The scientific community has taken notice of this phenomenon rather sporadically. The first larger analysis of this phonetic change was published by Westendorf in the middle of the last century (Westendorf 1962, p. 29). In his study, he was able to list a total number of seven examples. The existence of the phonetic change is clearly established on this base. In the next decades, research apparently has not turned to this topic anymore. In the literature no hints at further treatments can be found.

In the following lines new efforts to investigate this phonetic change are made. In the next lines, a few words should be said about the methodological approach. The first and foremost aim of this contribution will be to extend the data for this phenomenon in order to get a better picture of it. For this purpose, the material amassed in this paper will form a basis as broad as possible. The number of examples is significantly increased so that the phenomenon can be safeguarded better and better. The examples are chosen so that the phonetic change can run in both directions. The phonetic change can be documented on the one side in writings of single words. The same principle can be seen on the other side in word plays. The relevant word plays have been collected from - in the widest sense of the word - literary texts where they are traditionally to be expected. The article has been split into two parts both of which correspond to the duality of this phonetic change. The date of given evidence is added each time for the sake of clarity. The Old Kingdom is represented by two examples and the Middle Kingdom with at most one piece of evidence. The vast majority of the example has come from the

*Lecturer, University of Bonn, Germany. 
New Kingdom and Graeco-Roman Period. It is difficult to say whether this should be analyzed as evidence that the phonetic change has become more popular in a later stadium of the language history. The situation could as well be related to the randomness of historical records. In the future, new discoveries or previously overlooked examples could result in changes in the material. In view of this, the present lines are to be understood as a mere snapshot. However, the presentation of the following observations already seems legitimate at the current time. The vowels are not reproduced in the Egyptian script, which makes it difficult to reconstruct the original pronunciation of the words. In Egyptology, a modern transliteration system is used for the realization of words, being based merely on consonants. The contribution here is based also on this standardized tool.

\section{The Phonetic Change between "n" and "i" in Single Words}

The first section of this study is devoted to examples for the phonetic change in writings of single words. The basis of the argument shall be as broad as possible. To made orientation easier, an alphabetical scheme was chosen in the arrangement of the examples. In this way, unsightly back and cross references were avoided.

The first examples form a group, in the centre of which is the root "ib". The meanings can vary from case to case whereby the interpretation as such takes no harm. The writing "ib" (Sethe 1904, pp. 57, 8; Sethe 1904, pp. 60, 12) for "inb" "wall" presents the first example which should be mentioned in this context. The age of the example can be set in the Graeco-Roman Period. The main characteristic of this writing can be seen in the loss of "n", which could be brought in connection with this phonetic change. If this statement is acceptable, it has functioned as a basis for the assimilation of " $n$ " on " $i$ ". The assimilation of " $n$ " to "i" can be verified here after "i". The assimilation of " $n$ " to "i" has appeared in some other cases paid attention to by Westendorf (Westendorf 1962, p. 28). The assumption is probable that it was accompanied by the nasalization of the "n". The fact is known to the author that the suppression of the nasal has happened under other conditions as well (Jansen-Winkeln 1996, p. 36; Vittmann 2004, p. 150 n. 93). Without going further into detail, it may be possible that the loss of "n" has been motivated by phonetic changes in some of those other cases too. The answer to this question will be given in the near future. The next sentences will show explicitly that the assimilation of " $n$ " can be observed also before " $i$ ". In addition, there will be two examples for the elision of "i" in front of "n". Thus, the evidence points to the interactions between the two consonants as the origin of the phenomenon. The same phonetic change manifests itself in the writing "ib.t" (Edel 1975, p. 30; for the word "inb" "caracal" see Roquet 1977, p. 113ff.) for "inb.t" "she-caracal". The example in this case comes from the Old Kingdom. The example is particularly valuable because it leaves no doubt about the high age of the phonetic change. The original dark figure of the early examples could be much larger. The assimilation of " $n$ " to " $i "$ can also be detected in this example. The writing "ib" (Junker 1941, p. 96) for "inb" "part of a plant" can be explained by 
the same phonetic change. The age of the example can be set in the Old Kingdom. The cause of the writing is again formed by the assimilation of " $\mathrm{n}$ " to "i".

The writing "ibii" (Goedicke 1994, p. 74) for the verb "inb" has been stimulated also by this phonetic change. In the same way, the assumption of a metathesis would become necessary. The doubling of the "i" should not fall into the weight. The example belongs to the Graeco-Roman period. The semantic meaning of the verb "inb" has not been clarified by the editors of the "Wörterbuch" (WB I, 95, 11), while in the "Digitale Zettelarchiv" (DZA 20. 908.470) the translation "ummauern" has been elected. In the last case, a denominal derivation of "inb" "Mauer" would be present.

The phonetic change between " $\mathrm{n}$ " and " $\mathrm{i}$ " has also played a significant role in the writing "ir" (Chassinat 1966, p. 196) for "inr" "stone". The interpretation presupposes that " $\mathrm{n}$ " has been assimilated to " $\mathrm{i}$ " because of this phenomenon again. The alternative would be the assimilation of " $n$ " to " $r$ " which is considered here less likely. The age of the example can be given with the Graeco-Roman time.

The writing "iś" (Frankfort 1933, Pl. XXVII, Piankoff and Rambova 1954, pl. 23, 34,KRI I, 334, 1,Leitz1994, p. 137c,Leitz 2011, p. 240, DZA 24.672.230) for "niś" "to call" has been triggered also by this phonetic change. The writings came about through the assimilation of " $\mathrm{n}$ " to "i", again. The examples make it crystal clear that the assimilation of " $n$ " was carried out not only after "i" (compare the writings above), but also before "i". The examples cover a temporal framework from the New Kingdom to the Graeco-Roman period. When speaking of the verb "niś" "to call", its secondary form "nwś" (Wilson 1997, p. 491; Jasnow and Zauzich 2005, p. 186) should be named, which shows the influence of the phonetic change between " $\mathrm{i}$ " and " $\mathrm{w}$ ". The corresponding phonetic change is well known (Sethe 1899, p. 87f/116f, Edel 1955/1964, p. 62).

The writing "itš" for "intš" "tarantula" (Sauneron 1989, p. 54 (5),Vittmann 1991 , p. 239 ,Vittmann 2004 , p. 150 n. 93) seems to go back likewise to this phonetic change. In this case, the phenomenon again led to the assimilation of " $n$ " to "i". The frequency with which it had already occurred seems to speak for a fixed rule. The meaning "tarantula" is not entirely uncontroversial but is retained here for conventional reasons. The example can be dated in the Late Period.

The defective writing "bi" (Edwards 1960, p. 75 n. 42) for "bin" "bad" also finds an explanation in this phonetic change. If this assumption is correct, the phonetic change has brought with the assimilation of " $n$ " on "i" again. The example can be classified in the time frame of the Third Intermediate Period. The writing "bi.t" (Jansen-Winkeln 2005, p. 37 (21)) for "bin.t" in the women name "śt3-ir.t-bin.t" could belong to the same category. The last writing has been counted among the examples for the general loss of "n" by Jansen-Winkeln. In the explanation favoured here the influence of " $\mathrm{i}$ " is seen as more important, from which the assimilation of " $n$ " is thought to hang up. The example can be placed chronologically in the Late Period.

The writing "mti" (Jansen-Winkeln 1989, p. 238) for "mtn" "reward" also points in the direction of this phonetic change. It must be said that the form has been put down to the general loss of " $n$ " by Jansen-Winkeln. The interpretation 
chosen here, as a consequence of the phonetic change between " $\mathrm{n}$ " and "i", should be considered at least as close. Against the background of the other examples in this article, the assumption is quite obvious. The example belongs to the Third Intermediate Period.

The next example for this phonetic change comes in form of the writing "nii.t" for "inii.t" "inii.t"-seeds in: "nii.t n.t mhi" (Wreszinski 1912, p. 44, Wreszinski 1913, pp. 83-86, for "inii.t" "seeds" see Charpentier 1981, p. 82) "inii.t-seed of flax". If the suggestion can be confirmed, "i" has been ejected here in front of "n". The process can be called an aphaeresis of "i". The latter phenomenon can be proven several times in the Egyptian language (Erman 1967, pp. 96-104; Westendorf 1962, pp. 12-13; Kurth 2007, p. 463; for the term aphaeresis cf. Battist 1992, pp. 767-769, Glück 2005, p. 46). A second example for this will be encountered in the further course. The aphaeresis of "i" - which can be called "procope" by another term - will be treated in a second study in larger scale which is already in press. The consonant's weakness or semi-weakness will have promoted the process. The same behaviour can be observed for the two other weak/semi-weak consonants "3" and "w". The existence of the last two phenomena has been demonstrated quite often (Bojowald 2013, pp. 197-205, Bojowald 2015, pp. 39-42). The examples show that not only "n" could be eliminated before or after "i", but also "i" before or after "n". The above expression is written absolutely correctly in "inii.wt n(.w)t mhi" (Wreszinski 1913, p. 181) "seed of flax". The example under consideration can be assigned chronologically to the New Kingdom.

The phonetic change could also be recognized in the writing "nši" (Sethe 1906, p. 1309, 1. 20, Sethe 1906, p. 1306, 1. 3) for "nšni" "rage", in which it has lead to the assimilation of "n" on "i" again. The example can again be dated in the New Kingdom.

The writing "śikn" (Faulkner 1933, p. 53, Faulkner 1937, p. $178(25,11)$ ) for "śnik" "to destroy" apparently gives also testimony to this phonetic change. In this case, it has brought about a metathesis. The "Wörterbuch" (WB IV, 156, 8) has known the lexeme "śnik" "to destroy" only from the Middle and New Kingdom. The Graeco-Roman period can again be determined as the age of the example.

The writing "kni" (Gardiner 1914, p. 103 n. 2, Barta 1971, pp. 36-37) for "ki" "condition, state" could also be considered as result of this phonetic change. In this case, the phonetic change has caused the dissimilation of " $n$ " out of "i". The example therefore makes it clear that the development, beside assimilation, could also go in this direction. However, dissimilation appears to be less common. The age of the example can be given with Middle or New Kingdom. The dating in the Middle Kingdom is not quite sure because the text sources known today are stemming from the New Kingdom. Nevertheless, the literary work as such, being the "Prophecy of Neferty", has been composed in the Middle Kingdom. The possibility can thus not be ruled out, that the form has stood in the original version already. The text was intended to legitimize the seizure of power of king Amenemhet I. from the $12^{\text {th }}$ dynasty. 


\section{The Phonetic Change between "n" and "i" in Word Plays}

The second section of this study deals with examples for this phonetic change in word plays. The existence of the phonetic change between " $n$ " and " $i$ " is strongly supported by the writings mentioned before so this step seems now to be allowed. The formation of word plays has been very popular in Egypt (on word plays in Egyptian see Guglielmi 1984, pp. 491-506; Lippert 2001, pp. 88-100, Brunner-Traut 1978, p. 29, Barbash 2011, p. 16ff, Hagen 2012, pp. 52-54, Richter 2016, pp. 13-38, Derchain-Urtel 1984, pp. 55-61,Breyer 2003, pp. 13-22). The same development can be recognized in other ancient Near Eastern languages, by which the joy of the oriental in flowery speech is expressed. The surroundings of word plays have often emerged as the focal point of phonetic changes in the past. The interpretation of the following word plays is based on the guidelines of Leitz (2014, p. 310 n. 44), according to which the mere harmony is sufficient as a prerequisite. In connection with the same question, Fecht (1960, p. 114) claims that the creation of word plays is equivalent to a heuristic principle. In the contrast, Loprieno (2000, p. 7) comes to the conclusion that most word plays are lost to the modern viewer due to the lack of knowledge of the pronunciation. As highlighted above, the Egyptian texts only reproduce the consonants, while vowels are ignored in the script. The approach of Leitz is taken as model here. The source of the following word plays consists - as said in the introduction - of literary or semiliterary texts where they occur particularly frequently. The word plays offer a good opportunity to gain a much better impression of this phonetic change because they demonstrate that it was also used for stylistic purposes. The examples are again sorted alphabetically for a better overview.

The two following examples form a smaller group which consists of word plays built with "ii" "to come". The word play between "ii" "to come" and "nhh" "the old one" in: "nhh ii m nhb" (Morenz and Schubert 1954, p. 53) "the old one, who came out of the lotus flower. " will stand at the beginning, which additionally has profited from the phonetic change between " $\mathrm{i}$ " and " $\mathrm{h}$ ". The last phonetic change is attested in the Egyptian language well, which has been tackled by Westendorf (Westendorf 1962, p. 36). The requirements of the word play are all fulfilled so that it rests on a secure foundation. The person addressed can be found in the god Amon. The birth from the lotus flower may contain a solar connection. The creation period of the example can be set in the Graeco-Roman period. The phonetic change between " $\mathrm{n}$ " and "i" has also contributed to the word play between "ii" "to come" and "nn" "dark" in: "hśf.w śhm.w ii.w m nn" (Chassinat 1897 , p. 167, for this passage see also Leitz 2011, p. 14) "who drive back the powers who come in the nn-dark". The words describe the qualities of protective deities who are asked for help against evil demonic forces. The age of the example can be placed in the Graeco-Roman Period.

The next examples constitute a second group which contains word plays built with "iw" "to come". The examples will start with the word play between "iw" "to come" and "Nw.t" "Nut" in: "iw=k n mw.t=k Nw.t" (Kucharek 2010, p. 171) "May you come to your mother Nut" where Osiris has been put under the tutelage of the heaven goddess Nut. The god Osiris could be seen as son of this female 
deity. The loss of the feminine " $t$ "-ending does not matter much because it was handled relatively freely. The age of the example again indicates the GraecoRoman period. The word play between "iw" "to come" and "nwn" "Nun" in: "iw nwn n hnti mhii.t m-hnw ntr pn št3" (Oswalt 1968, p. 160) "The Nun comes in the southward-going north wind within this mysterious god." can also be explained with this phonetic change. In an additional way, it has benefited from the loss of " $n$ " at the end of the word. The last phenomenon can be explained by the assimilation of " $n$ " to "w", for which the phonetic change between " $w "$ and "n" may be responsible. In the Egyptian language, the last phonetic change is attested several times (Westendorf 1962, p. 22). In terms of its age, the example can be dated to the New Kingdom. The word play between "iw" "to come" and "niw.t" "town" in: "iw=k r niw.t=k tp 3.t mri ib=k" (Leitz 2011, p. 315) "you may enter your city in the moment your heart are wishing for." is apparently also influenced by the phonetic change between " $n$ " and "i". In this case, it has triggered the assimilation of " $n$ " to " $i$ " again. The loss of the feminine " $t$ "-ending is no problem, for which the remarks above can be compared. The passage alludes to the afterlife of the deceased. The most important goal was freedom of movement among others, the achievement of which is promised in these words. The dating in the Graeco-Roman period can also be used for this example.

The next example for this phonetic change has been provided by the wordplay between "iri" "to do, to make" and "rn" "name" in: "ntt niw.t iri niw.wt $\mathrm{r}$ rn=ś" (Sethe and Firchow 1957, p. 37 o 2) "fore thou are the city, in whose name the cities has been founded" (Sternberg-El Hotabi 1993, p. 134). The word play also lives from the "i"-aphaeresis which has already been used as explanation for other examples above. The words are documented in a praise song of the city of Thebes where its pre-eminence over the other cities is emphasized. The origin of all cities is traced back to this cultic centre. The dating in the Graeco-Roman period also applies to this example.

The word play between "bi.t" "honey" and "bnr" "sweet" in: "bi.t hí Imn, mn=k ir.t hr bnr hr ib=k" (Tacke 2013, pp. 2012-2013, for the word "bi.t" "honey" see Helck 1963, p. 703ff.) "bi.t-honey, 1 pot: Amon, take yourselves the eye of Horus which is sweet upon your heart" maybe came also into existence through this phonetic change. In this case, it appears together with the phonetic change between " $\mathrm{i}$ " and " $\mathrm{r}$ " which occurs generally very often in the Egyptian language (Westendorf 1962, p. 32). The word play has perhaps included the word "ib" "heart", as well. The text passage can be found in an offering instruction. In the past, the king AmenhotepI. was interpreted as the recipient, which has now be changed in favour of the god Amon. The term "eye of Horus" is used as a code word for the honey. The real-world background can be observed in the "Myth of Horus and Seth", in which the eye of the falcon god Horus was first injured and then healed again. The "Myth of Horus and Seth" can be counted among the most famous literary works of the New Kingdom. The struggle of the gods Horus and Seth for the inheritance of Osiris thus acted as a mythical precedent. The god Horus emerged from this conflict as a victor and was placed on his father's throne. The motif thus serves as a symbol for the restoration of the right order. The age of the example above points to the New Kingdom. 
The same phonetic change seems to return in the word play between "sinw" "physician" and "iśw" "payment" in: "mi p3 sinw nfr, mk wii mn.kwi m ir.t=i, ih $\mathrm{di}=\mathrm{k}$ śnb=i har - '.wi, iri.n=i n=k m iśw-iri" (Wild 1958, p. 409, for a metrical analysis of this sentence see Fecht 1963, p. 95; for the word "sinw" "physician" see Lacau 1972, p. 47, Hannig 2004, p. 86) "Come, good physician. Look my eye ails me. May you make me healthy immediately! I have made you this as payment". The word play requires the assimilation of " $n$ " to " $i "$. The difference in the two sibilants is not serious since the transitions here were partly smooth. The example can be dated from the historical time in the Late Period. The words are part of an inscription chiselled on the base of a statue. The words go to the address of Amenhotep, son of Hapu, who is called as rescuer in need. The prominent figure of the $18^{\text {th }}$ dynasty lived under the reign of king Amenhotep III. and was venerated by the population of the Nile valley in the Late Period as sage and wise man. The development went so far that he had become the patron saint of doctors in this period. The author of the words quoted has hoped for medical help from him. The praying man brings a gift to the demigod. The word "sinw" "doctor" is used as a kind of honorary title. The action can be seen in the context of "personal piety" the beginnings of which go back mainly to the New Kingdom. However, the first timid forerunners can be encountered in the period before.

\section{Conclusion}

The time has now come to summarize the results of this study. In this sense, the evaluation could go in the following direction: The phonetic change between " $n$ " and " $i "$ has been put on a broader basis by the examples mentioned. In the total, twenty-two examples could be collected. The number has more than tripled compared to Westendorf. The bottom line is that the phonetic change appears to be more common than previously thought. The phonetic change has developed from "n" to "i" as well as from "i" to "n". The phenomenon can be followed almost throughout the whole Egyptian language history. The time frame of the examples spanned from the Old Kingdom to the Graeco-Roman Period. According to the examples known up to now, the climax seems to be in the younger phase. However, the situation can change very quickly as a result of new discoveries ore previously overlooked material. The remarks above have given the phonetic change back its actual home right in this idiom.

\section{References}

Barbash, Y (2011) The Mortuary Papyrus of Padikakem. New Haven: Walters Art Museum 551, YES 8.

Barta W (1971) Zu einigen Textpassagen der Prophezeiung des Neferti (On some text passages in the prophesy of Neferty). MDIK 27(1): 35-45.

Battist D (1992) Aphaerese (Aphaeresy). In G Üding (ed.), Historisches Wörterbuch der Rhetorik. Band I. Berlin. 
Bojowald S (2013) Zum Ausfall von anlautendem "w" im Ägyptischen (On the Egyptian loss of "w" at the beginning of the word). AuOr 31(2): 197-205.

Bojowald S (2015) Neue Beispiele für den ägyptischen Ausfall von "3" zu Beginn des Wortes (New examples for the Egyptian loss of "3" at the beginning of a word). AuOr 33(1): 39-42.

Breyer F (2003) Wortspiele in zwei hymnischen Abschnitten der Traumstele (Word plays in two hymnic sections oft he Dream Stela). LingAeg 11: 13-22.

Brunner-Traut E (1978) Altägyptische Literatur (Old Egyptian Literature). In W Röllig, Altorientalische Literaturen, Neues Handbuch der Literaturwissenschaft. Band 1. Wiesbaden.

Charpentièr G (1981) Recueil de matériaux épigraphiques relatifs a la botanique de $l$ Égypte Antique (Collection of epigraphic materials relating to the botany of Ancient Egypt). Paris: Imprimerie Trismegiste.

Chassinat É (1897) Le temple d'Edfou (The temple of Edfu). Tome Premier, Mémoires publiés par les Membres de la Mission Archéologie Française au Caire, Tome Dixième. Paris: Imprimerie Française et Orientale de L. Marceau.

Chassinat É (1966) Le mystère d' Osiris au mois de Khoiak (The mystery of Osiris in the month of Khoiak). Fascicule I. Le Caire: Publications de 1' Institut Français d' Archéologie Orientale du Caire.

Derchain-Urtel M-T (1984) Wortspiele zu „Ort“ und „Bewegung“ in Edfu und Dendera (Word plays for "place" and "movement" in Edfu and Dendara). Montpellier: Melanges Adolphe Gutbub.

Edel E (1955/1964) Altägyptische Grammatik (Ancient Egyptian grammar). Bd. I und II Oldegyptian Grammar, Bd. I and II -, AnOr 34 + 39. Rome: Pontificium Institutum Biblicum.

Edel E (1975) Beiträge zum ägyptischen Lexikon VI (Contributions to the Egyptian lexicon VI). ZÄS 102: 13-30

Edwards IES (1960) Hieratic Papyri in the British Museum, Fourth Series, Oracular Amuletic Decrees of the Late New Kingdom. Vol. I. Text. London: The Trustees of the British Museum.

Erman A (1967) Assimilation des Ajin an andere schwache Konsonanten (Assimilation of Ajin on other weak consonants). ZÄS 46: 96-104.

Faulkner RO (1933) The Papyrus Bremner-Rhind. BibAeg III. Bruxelles: British Museum No. 10188.

Faulkner RO (1937) The Bremner-Rhind papyrus III. JEA 23: 66-185.

Fecht G (1960) Amarna-Probleme (1-2) (Amarna-Problems (1-2)). Z̈̈S 85: 83-118.

Fecht G (1963) Die Wiedergewinnung der altägyptischen Verskunst (The rediscovery of the old Egyptian vers art). MDIK 19: 54-96.

Frankfort H (1933) The cenotaph of Seti I at Abydos. Volume II: Plates. EES 39, Order of the Committee.

Gardiner AH (1914) New literary works from Ancient Egypt. JEA 1: 100-106.

Glück H. (Ed.) (2005) Metzler Lexikon Sprache (Metzler Lexicon Language). 3. Auflage. Stuttgart-Weimar.

Goedicke H (1994) Comments on the "Famine Stela". VAS 5. San Antonio: van Siclen Books.

Guglielmi W (1984) Zu einigen literarischen Funktionen des Wortspiels (On some literary functions of the word play). Studien zu Sprache und Religion Ägyptens, Band 1, Festschrift für W. Westendorf. Göttingen: Hubert \& Co.

Hagen F (2012) An ancient Egyptian literary text in context, the instruction of Ptahhotep, OLA 218. Leuven-Paris-Walpole/MA. 
Hannig R (2004) Beiträge zur Lexikographie 1: Mögliche Phantomwörter im HL 1 (Contributions to Lexicography: Possible phantom words in HL 1). In G Takács (ed.), Egyptian and Semito-Hamitic (Afro-Asiatic) Studies in Memoriam W. Vycichl, Studies in Semitic Languages and Linguistics 39, 69-97. Leiden/Boston: Brill.

Helck W (1963) Materialien zur Wirtschaftsgeschichte des Neuen Reiches (Teil IV), III. Eigentum und Besitz an verschiedenen Dingen des täglichen Lebens, Kapitel P-AH (Materials for the economic history of the New Kingdom (Part IV), III. Ownership and possesion of different things of the daily life, chapter P-AH). Akademie der Wissenschaften und der Literatur, Abhandlungen der Geistes- und Sozialwissenschaftlichen Klasse Jahrgang 1963 - Nr. 3. Wiesbaden: Verlag der Akademie der Wissenschaften und der Literatur in Mainz, in Kommission bei Franz Steiner Verlag $\mathrm{GmbH}$.

Jansen-Winkeln K (1989) Zwei Bemerkungen zu Gebel es-Silsila Nr. 1oo (Two remarks on Gebel es-Silsila Nr. 100). JEA 75, 237-239.

Jansen-Winkeln K (1996) Spätmittelägyptische Grammatik der Texte der 3. Zwischenzeit (Late Middle Egyptian Grammar of the texts of the Third Intermediate Period). ÄAT 34. Wiesbaden: Harrassowitz Verlag.

Jansen-Winkeln K (2005) Ein Priester als Restaurator, Zu einer ptolemäischen Inschrift am Luxortempel (A priest as restaurator, On a ptolemaic inscription at the Luxor

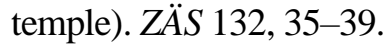

Jasnow R, ZauzichK-T (2005) The ancient Egyptian book of Thot, A demotic discourse on knowledge and pendant to the classical Hermetica. Volume 1: Text. Wiesbaden: Harrassowitz Verlag.

Junker H (1941) Giza V. Bericht über die von der Akademie der Wissen-schaften in Wien auf gemeinsame Kosten mit Dr. Willhelm Pelizaeus unternommenen Grabungen auf dem Friedhof des Alten Reiches bei den Pyramiden von Gîza, Band V, Die Mastaba des śnb (Seneb) und die umliegenden Gräber (Giza V. Report on the work carried out by the Academy of Sciences in Vienna at joint expense with Dr. Willhelm Pelizaeus undertook excavations in the cemetery of the Old Kingdom near the pyramids of Gîza, Volume V, The Mastaba des śnb (Seneb) and the surrounding graves). Wien/ Leipzig: Akademie der Wissenschaften in Wien, Philosophisch-historische Klasse, Denkschriften, 71. Band, 2. Abhandlung.

KRI I=Kitchen KA (1975) Ramesside Inscriptions I: Historical and Biographical. Oxford.

Kucharek A (2010)Altägyptische Totenliturgien Band 4, Die Klagelieder von Isis und Nephthys in Texten der Griechisch-Römischen Zeit (Old Egyptian death liturgies Band 4, The lamentations of Isis and Nephthys in texts of the Greco-Roman time). Supplemente zu den Schriften der Heidelberger Akademie der Wissenschaften, Philosophisch - historische Klasse Band 22. Heidelberg: Universitätsverlag Winter.

Kurth D (2007) Einführung ins Ptolemäische, Eine Grammatik mit Zeichenliste und Übungsstücken, Teil 1 (Introduction into Ptolemaic, A Grammar with sign list and lessons, Part 1). Hützel.

Lacau P(1972) Études d'Égyptologie, II. Morphologie (Studies of Egyptology, II. Morphology). BdE 60. Le Caire: Publications de 1' Institut Français d’ Archéologie Orientale du Caire.

Leitz C (1994) Tagewählerei, Das Buch ḩ3.t nhh ph.wy d.t und verwandte Texte Tagewählerei (The Book ḥ3.t nḥ̣ ph.wy d.t and similar texts - Textband). ÄgAb 55. Wiesbaden: Harrassowitz Verlag.

Leitz C (2011) Der Sarg des Panehemisis in Wien (The coffin of Panehemisis in Vienna). SSR 3. Wiesbaden: Harrassowitz Verlag.

Leitz C (2014) Die Gaumonographien in Edfu und ihre Papyrusvarianten, Ein überregionaler Kanon kultischen Wissens im spätzeitlichen Ägypten (The nome 
monographies in Edfu and their papyrus variants, A overregional canon of cultic knowledge in Late period Egypt). Soubassementstudien III, Teil 1: Text, SSR 9. Wiesbaden: Harrassowitz Verlag.

Lippert SL (2001) Komplexe Wortspiele in der Demotischen Chronik und im Mythus vom Sonnenauge (Complex word plays in the demotic chronicle and myth of the solar eye). Enchoria 27, 88-100.

Loprieno A (2000) Puns and word plays in ancient Egypt. In S Noegel (ed.), Puns and Pundits, Word Play in the Hebrew Bible and Ancient Near Eastern Literature. Bethesda.

Morenz S, Schubert J (1954) Der Gott auf der Blume, Eine ägyptische Kosmogonie und ihre weltweite Bildwirkung (The god on the flower, An Egyptian Cosmogonie and its worldwide influence). Ascona: Verlag Artibus Asiae.

Oswalt JN (1968) The Concept of Amon-Re as reflected in the Hymns and Prayers of the Ramesside Period. Ann Arbor: University Microfilms Inc.

Piankoff A, Rambova N (1954) The tomb of Ramesses VI, Plates, Egyptian religious Texts and Representations. Vol. I, Bollingen Series 40. New York: Pantheon Books.

Richter BA (2016) The Theology of Hathor of Dendera, aural and visual scribal techniques in the Per-Wer sanctuary. Atlanta: Wilbour Studies in Egyptology and Assyriology Number 4.

Roquet G (1977) Le nom du "Lunx", I(N)B comme anthroponyme (3 ${ }^{\mathrm{E}}$ Dynastie) (The name of the "Lunx", I (N) B as an anthroponym (3rd Dynasty)). BIFAO 77, 113-117.

Sauneron S (1989)Un traité égyptien d' ophiologie. Papyrus du Brooklyn Museum $N^{\circ} 47.218 .48$ et .85 (An Egyptian treatise on ophiology. Brooklyn Museum Papyrus No47.218.48 and .85). BibGen 11. Le Caire: Institut Français d' Archéologie Orientale du Caire.

Sethe K(1899) Das aegyptische Verbum im Altaegyptischen, Neuaegyptischen und Koptischen (The Egyptian verb in old Egyptian, late Egyptian and Coptic). Erster Band, Laut- und Stammeslehre. Leipzig: J. C. Hinrichs'sche Buchhandlung.

Sethe K (1904) Hieroglyphische Urkunden der griechisch-römischen Zeit (Hieroglyphic documents of the Greco-Roman Period). Urkunden des ägyptischen Altertums, Abteilung 2. Leipzig: Hinrichs'sche.

Sethe K (1906) Urkunden der 18. Dynastie (Documents of the $18^{\text {th }}$ dynasty). Urkunden des ägyptischen Altertums, Abteilung 4. Leipzig: Hinrichs'sche.

Sethe K, Firchow O (1957) Thebanische Tempelinschriften aus griechisch-römischer Zeit I (Theban temple inscriptions from the Greco-Roman period I). Berlin: AkademieVerlag.

Sternberg-El Hotabi H (1993) Der Propylon des Month-Tempels in Karnak-Nord, Zum Dekorationsprinzip des Tores, Übersetzung und Kommentierung der Urkunden VIII, Texte Nr. 1-Nr. 50 (The Propylon of the Month temple in Karnak-North: on the decoration principle of the Gate, translation and commentary of the Urkunden VIII, Texte Nr. 1-Nr. 50). GOF IV Reihe: Ägypten, Band 25. Wiesbaden: Harrassowitz Verlag.

Tacke N (2013) Das Opferritual des Ägyptischen Neuen Reiches, Band II: Übersetzung und Kommentar (The offering ritual of the Egyptian New Kingdom, Band II: Translation and Commentary). OLA 222. Leuven: Editions Peeters.

Vittmann G (1991) Rezension zu: Sauneron, Serge: Un traité égyptien d' ophiologie. (Review on: Sauneron, Serge: An Egyptian treatise on ophiology). Papyrus du Brooklyn Museum Nº7.218.48 et .85 (= Publications de 1' Institut Français d' Archéologie Orientale, Bibliothèque Générale, t. XI). Le Caire: Institut Français d' Archéologie Orientale, 1989. XI + 243pp.; 21 seitiger Anhang mit (unnumerierten) Tafeln und hieroglyphischen Transkriptionen, WZKM 81, 237-234. 
Vittmann G (2004) Iranisches Sprachgut in ägyptischer Überlieferung (Iranian language elements in Egyptian tradition). In T Schneider (ed.), Das Ägyptische und die Sprachen Vorderasiens, Nordafrikas und der Ägäis, Akten des Basler Kolloquiums zum ägyptisch-nichtsemitischen Sprachkontakt. Basel 9-11 Juli 2003, AOAT 310. Münster: Ugarit Verlag, 129-182.

Vycichl W (1990) La vocalisation de la langueÉgyptienne, Tome ${ }^{e r}$, La phonétique (The vocalization of the Egyptian language, Volume I, Phonetics). BdE 16. Le Caire: Institut Français d' Archéologie Orientale du Caire.

WB I=Erman A/Grapow H (1926) Wörterbuch der Aegyptischen Sprache Band 1 (Lexicon of the Egyptian Language Band 1). Berlin.

WB IV=Erman A/Grapow H (1958) Wörterbuch der Aegyptischen Sprache Band 4 (Lexicon of the Egyptian Language Band 4). Berlin.

Westendorf W (1962) Grammatik der medizinischen Texte (Grammar of the medical texts). Grundriss der Medizin der alten Ägypter VIII. Berlin: Akademie-Verlag.

Wild H (1958) Ex-voto d'une princesse Saïte à l' adresse d' Amenhotep-fils de Hapou (Ex-voto of a princess Saïte at the address of Amenhotep-son of Hapou). Festschrift zum 80. Geburtstag von Professor Dr. Hermann Junker, II. Teil. MDIK 16, 406-413.

Wilson P (1997) A Ptolemaic Lexikon, A lexicographical Study of the texts in the temple of Edfu. OLA 78. Leuven: Uitgeverij Peetersen Departement Oosterse Studies.

Wreszinski W (1913) Der Papyrus Ebers, Umschrift, Übersetzung und Kommentar, I. Teil: Umschrift (The Papyrus Ebers, transcription, translation, and commentary, Part I: Transcription). Leipzig: J. C. Hinrichs'sche Buchhandlung. 
